Louisiana State University

LSU Digital Commons

1957

\title{
The Immediate Effects of Emotionality Upon Behavior Strength.
}

Norman R. Ellis

Louisiana State University and Agricultural \& Mechanical College

Follow this and additional works at: https://digitalcommons.Isu.edu/gradschool_disstheses

\section{Recommended Citation}

Ellis, Norman R., "The Immediate Effects of Emotionality Upon Behavior Strength." (1957). LSU Historical Dissertations and Theses. 184.

https://digitalcommons.Isu.edu/gradschool_disstheses/184

This Dissertation is brought to you for free and open access by the Graduate School at LSU Digital Commons. It has been accepted for inclusion in LSU Historical Dissertations and Theses by an authorized administrator of LSU Digital Commons. For more information, please contact gradetd@lsu.edu. 


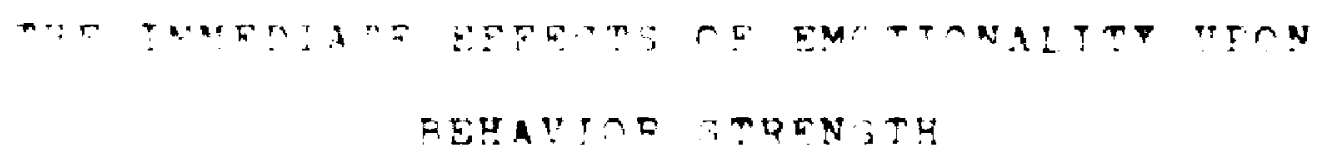

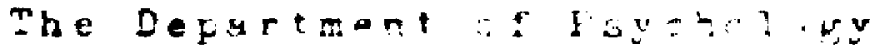

\footnotetext{
by

Norman R. E1118

A. B. Howard College. 1951

M. A., Iniveralty of Alahama, IO5J

January, 1957
} 
AC KNOLEDONENT

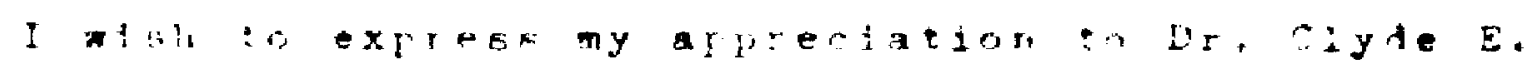

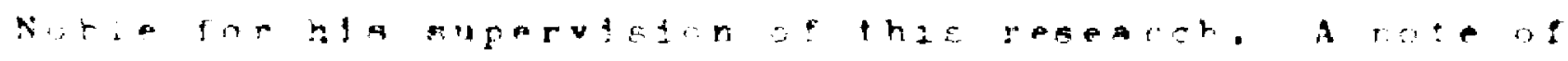

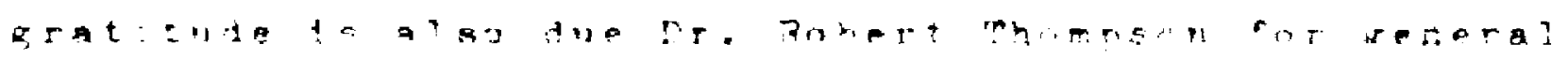

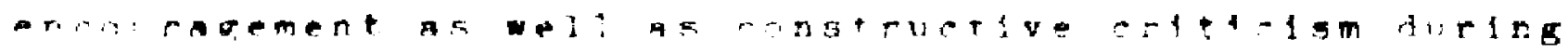

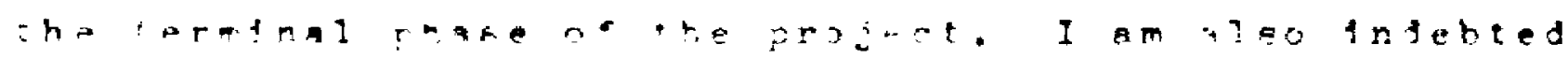

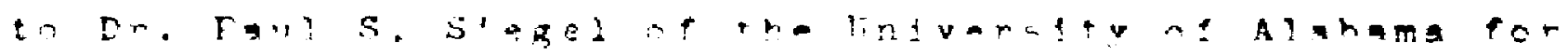

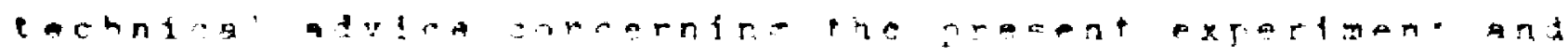

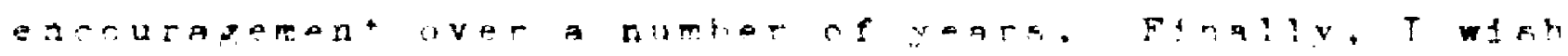

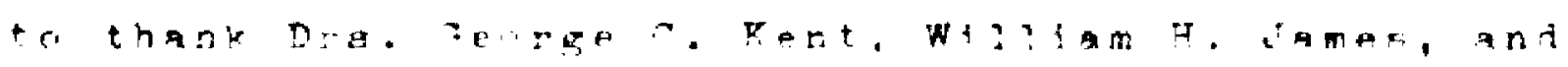

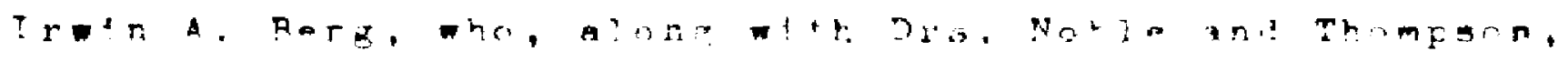

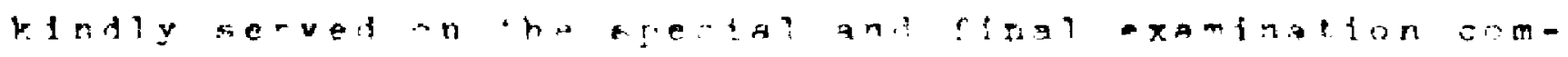
mitte 
TABLF OF CONTENTS

PAGE

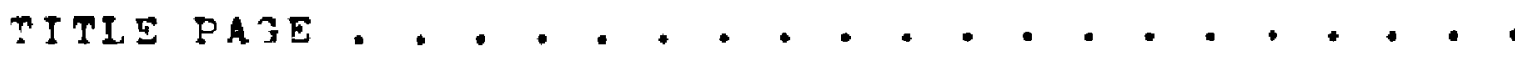

ACRNOWLEDGMENT

11

LTST OF TARLES

$1 v$

LIST OF FITU?ES

ARSTRACT. . . . . . . . ................ v1

INTROTUCTTIN

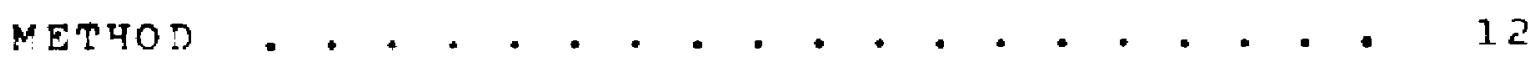

Subjects.................... 12

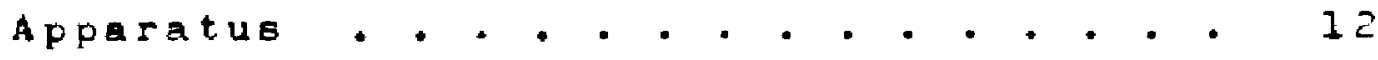

procedurt . . . . . . . . . . . . . 13

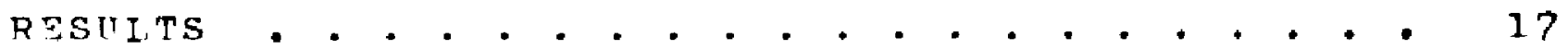

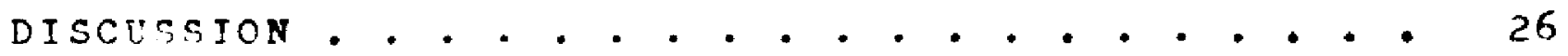

SITMARY • • • • • • • • • • • • • • • • • • • • 35

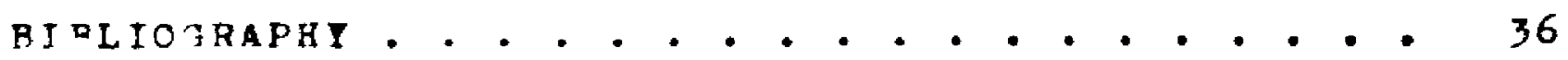

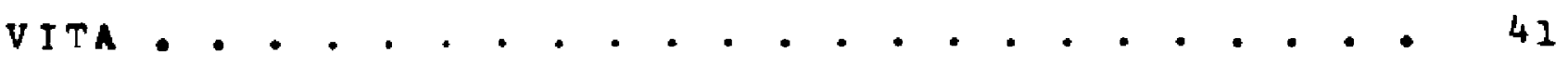




\section{LIST OF TARLES}

TA BLE

PAGE

I Average Latency as a Function of Treat-

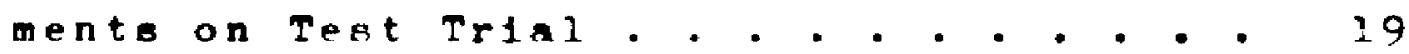

I Summary Analyois of Vartance of Latency

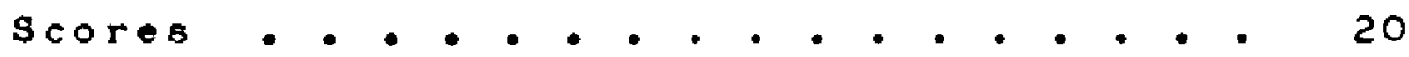

II Avergae Running Time as a Fuction of Treatments on Test Trtal .......... 23

IV Summary Analysts of Variance of Running Tjme Scores.................. . . . 24 


\section{LIST OF FIGURES}

FIFURE

PATE

1 Median Latency as a Function of Trainina

$$
\text { Days and Treatments.......... . . } 18
$$

2 Median Runing Time as Function of

$$
\text { Training Days and Treatments . . . . . } 22
$$




\section{ARSTRACT}

Contenporary hehavior theory employs three main clasoes of variables in an attempt to predict behavior. These are motivation, learning, and inhibitory factoro. Hull alone has attempted to quantify the interrelation of these varlables. He postulates that hehavior otrenoth is multiplicative function of a learning factor, habit, and motivational factor, drive. The total effective drive operative at a oiven time is presumed to consist of the relevant drive plus any coexisting irrelevant drives.

In order to test this drive sumation hypothesis, 126 rats were trained to run a linear, alley maze while under 23-hr. hunger need. Following 21 dety training trials the animals were asolgned to nine treatment groupo consisting of the possible combinations of 0,12 , and 23 hrs. food privation, as a relevant need, with zero, weak and strong paradic stimulation, as an irrelevant need. The "test consisted of a trial similar to training trial." The atate induced by the faradic otimulation wao called emotionality and viewed as possesaing motivational properties. Both otart box latency and maze running time were utilized as criterion behavior. 
The findinga were matnly negative. The criterion behavior was not significantly influenced by the introduction of an irrelerant need into the motivational complex. Af expected, changes tn the relevant need otate did significantly affect latency and running time. A near significant rolevant need-irrelevant need intoraction was observed. Several poseibje ways of modifying the theory to account for more of the fresent experimental data were discussed. It was concluded that the present data provided no derinitive evidence elther for or against the theory. 


\section{TNTRODUCTTPN}

Contamporary behavior theory omploys three main clasfes of variablor in an attempt to preotot hehavior.

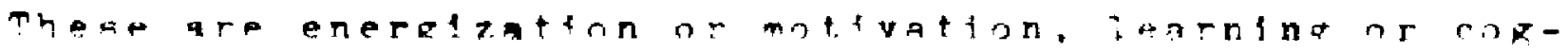
nttisn, and tecremental or inhtritory factors (....... fatisue, reactive (nhthitton). Cithoge, the pormer two orohahly have rereived mofit attention. of rourae.

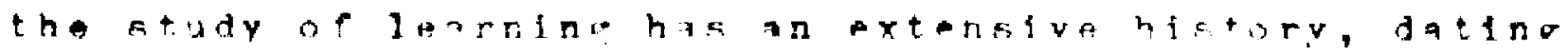
from the time of Ebhthahnug. Though thr formal study omotivation is not as old, renewed intarertinthr vartable is attested to hy soveral recent putifotions $\left(13,1^{t}, 25,1^{9}\right)$. Of thr modern theorists, Hull alone has attemptel to formulataln a quantitative fashion the interrelation of learning. inhirftory, and motivational factors.

Hul (II) postulatea that helavior stopogth is multiplicative function of a learning fartor, hath otrength ( $\left.s^{4} r\right)$, and a motivational factor, generalized drive (n). The term "behavior strength" sas used throughout thin paper 38 , In oneral, equivalent to Hull's concept of s, momentary effective reaction potantial. In otating the detarminanto of Er, constructa othar than ${ }^{H} r$ and $D$ have heen omftted. ${ }^{H} r$ to defined by changea 


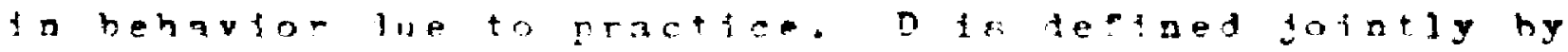
oragter anergization of hehavior following ouch nntecodent anditions as deprivation of fond and roxiout Etimulation. Huli then hypothesized that tho total effectivedrtye atrength (D) operative at a given amount

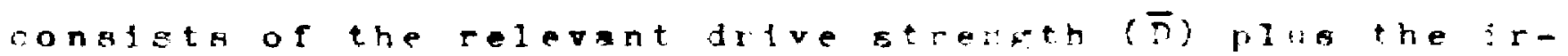
relevant driventrength (D) derlved from al neels comisting in the trgantsm. $\bar{\Gamma}$ is cortrinuted by tho need which is redust hy the criterion hphavtore whereag D ts contributed by needs which orehistorically unrelated to the criterion hehaving and whose extatence is derined by 1. nterentent operationa.

Appirentlv, Hu:? arrtyed at tho nation of drive mummation hy fitting, o cure to datacoliected hy fertn izl and W1 T19ms (20). In thitependent atudios these 1nvestigatore trained rata to prenk a pever to obtaln nel?ets of food in a skinner hox. After tratning.thatantmisinehavior was extingufohed under food privation intorvalo rangino from 3 to 22 hrs. ay fitting a curveto the resulta and extrapolating back to a polnt of zero D. Hull noted thet the number or responses to extinction was a per cont as great as ocelired under a drjve resilting from 22 hro. food privation. Unfortunately. no animalo wero actunily tekted under zeroD. This finding, Hull 


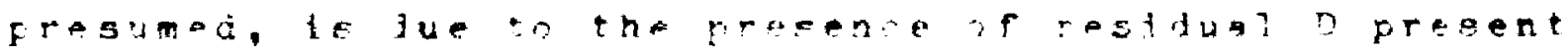
at the time of extinetor. He adduret furphor evidence to suport thls be? lef from studiesty zener and Macurdy (30), Finah (ic), ant seingar (pr).

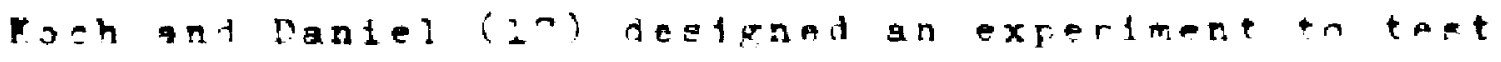

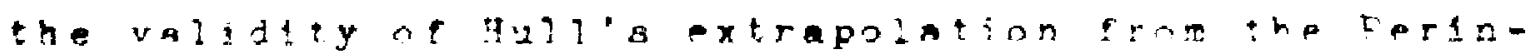

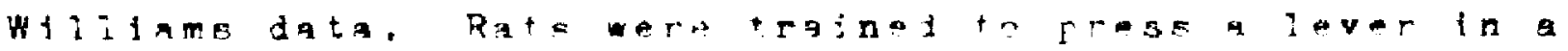

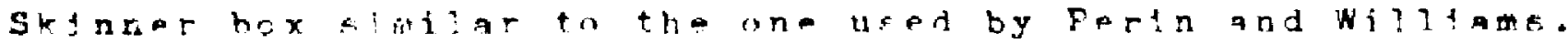

The andalb were tratrod under trong hinger and ex-

tingutehed unter conditions deolgned toprovide maximal

satiation. The modian number of responses in extiention wat one, and tt was concluded that this small value eugsests the tube behavior potential is zern. The authore believe the assumptionthat $\dot{D}$ gomples wh hablt otructurea to ponduce hehavior ls highly tervous. However, it ghould he palated out that this otudy doen not provide a defteltioe test of thie asumpton, ofnce no attemptwas male to marjpulate $\dot{D}$ efr

Followigg these enrly studioe. Which dealtonly indirectly with the problew of drive sumation, experitents wero specificaliy dostgned to teat thio hypothesis. These etudies divide themselres into those concerned ith conEugatory behavior and thooe doaling with preparatory hehar $10 \mathrm{r}$ 


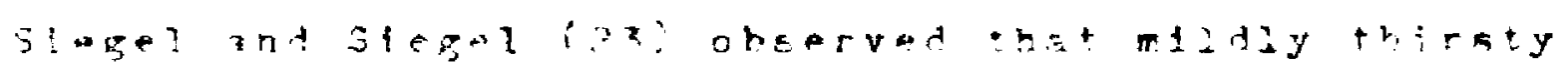
rats sentuing faradic stimlation tamediutely pricr to drlaking, drank aore water than non-et:angtadentrol animile. Their ftnitiz was taterpreted withinthe framework wi a molerular theory of thirst. Ir a similar. 10

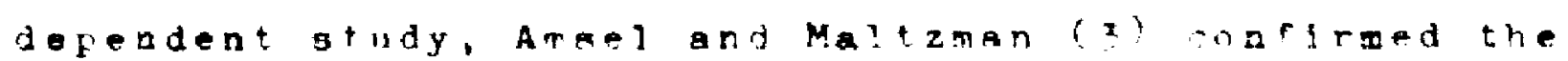
empirical finding of stegel ond stegel. Homever, thene tnvestlgatora offered their results gr surgort for Hu? Generalizel drive witing. Furthermore, they contended

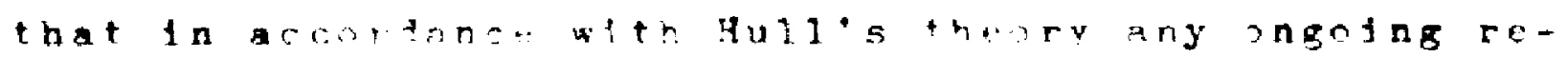
aponse would have hepo sugmented by the adrition of D.

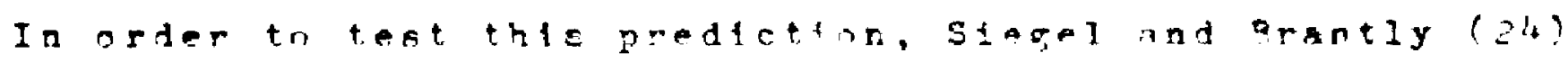

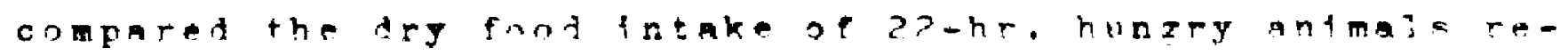
cetring faradic st+mulation lmmediately grior to eating with non-atimulated controts. The expertmental animals were bhocked by an w wh had no other crntart with than and $1 \mathrm{n}$ a rom other than the familiar tost ronm. rhis procedure wan desfgned toprevent responsep which might compete with the criterion behavior from carryng over to the test situation. It was found, in keeping with HuIles theory, that the omotional animalo dident woredry food than the non-emotional control animalk.

In later etudy, El11s, siegel, and Wonl (8) tested antmale under conditione chich ahould have proven even 
more favorabe to 4 ull's thenry. In all asperta tha experiment waf identica? to tho one by siegel int Prantley except that $\bar{D}$ was generated hy 4 hrs. food privation. Under thee conditions atatiaticaliy stginfirant decrement in dry food intake was produced hy the induced emotfonality. A subsequent study (29) in the ame laborotory replicated the siegel and arantley etudy. Their inting was corroborated. Thus it was concluded, on the basis of these two studies, that the efferte of the addition of $\dot{D}$ to a motivational complex is hifily contingent upon the level of $\overline{\mathrm{D}}$.

several studies have been concerned with the effecto or $\dot{D}$ upon neeparatory rehaglor. Kendier $(16)$ trafand five groupe of -ats in stinner hor under 22 hrse fon prtvetion plus $0.3, f_{1}, 12$, and 22 hra.tilest. ThitgreInforcemento wre orven under these drive conditions, and thon the behorior was extingulahed the following day under identical motivational conditione. viewing responses to extinction a the criterion behavior, it war found that induced by 3,6 , and 12 hrs. thirst ofgnificantiy increased the number of responses to axtinction when coupared to o group. The 22-hr. group bhowed a bigificant decrement when compared to any other group. Iater, as siegel (22) pointed out, Kendier recognized that his results are confounded by the differential drive conditions 
Niritir latritho.

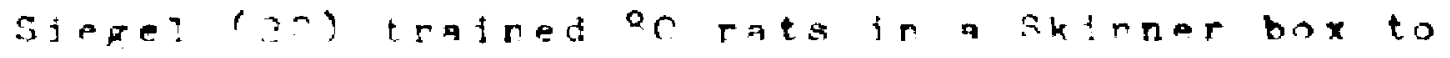
press a jever for fond peliete. One ary of (40) anirole rezetued 40 reinforcementrand th rematning or up of (40) rectived5 -teforements. These lwo groups were

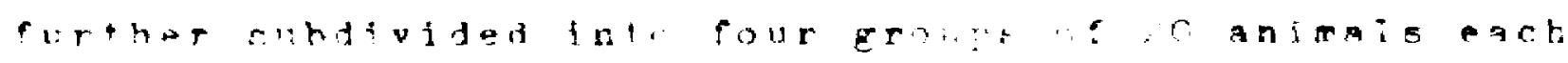

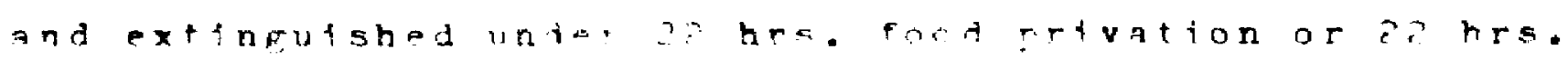
food frivatior riuk zighs. watergrivition. The ad-

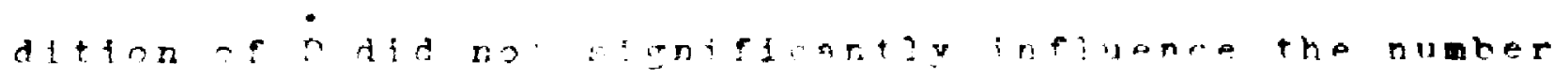

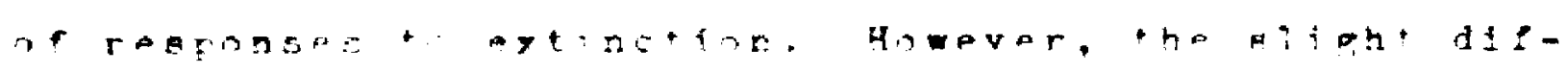

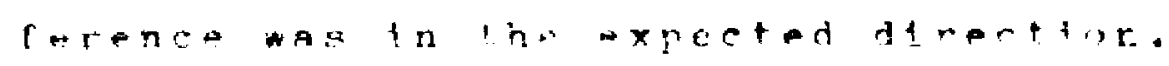

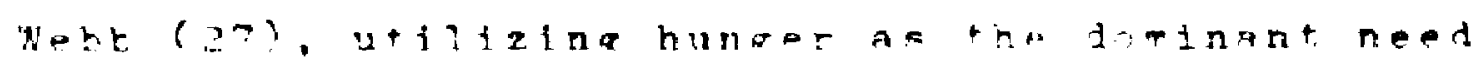

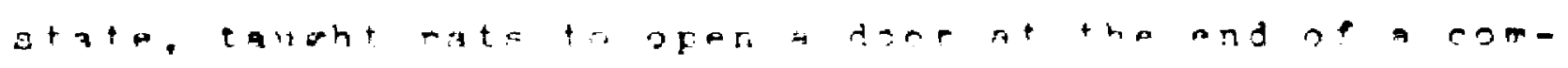
portmant to ohtain food. Followtaptraining, the animals

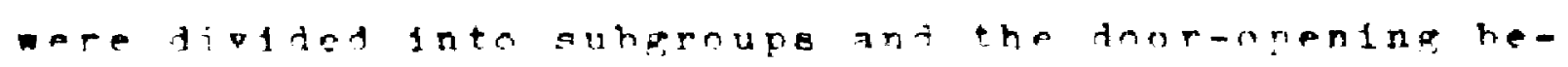
havior etefnzuished under $0,3,12$, and? hro. water privation while satiated for cood. In teras of trials to extinction, $\boldsymbol{o}^{\dot{\bar{E}}} \mathbf{r}$ as difrectly and linearly related to the strength of the frrelevant thist need. This has been confirmed by Erandauer (5).

In each of the foregolng tudies which were concerned with preparatory behavior the inveatigator has attempted to complae needs determined by food and water privation. This chotce of needs meets with difficultes, a han been observed by Ausel (1). Sinplj stated, a 
hunory antma: may aloo he a thirsty antmai, and the coriverae may also he trio. In vien of this rossiblaconfounding, othor studief have employed needs which appar to be more independent.

$$
\text { strange (26) condftioned rats to preag a lever } 1 \leq \text { a }
$$
modifled skinner hox to aveld light. The fituation was arranfed so that an antmal could turn off a light for 58 sac. by depmeasint, a lever. Each antmal was plared in the box for 15 min. per day unt:l 59 relnforcemente had occurred. Sunsoo:ently. the 44 mntmalo were sutdivided into four equal groupe and extingulshed unter the lirht

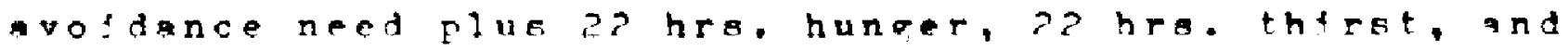
2? hro. hunger plus?? hro. thfrot. The extfnetion procedure conalsted of nlacing the nnimal in the attuation for a T-min. period each day for lo day. In terme of total number of extinction responses occurring during this period, no significant differences were observed.

An experiment by Amgel (1) conotituteo rigorous test of the generalized drive hypothesio. One hundred and forty four rats were adapted to a 4 ft. runway which had a grid floor through which the animal could recelve an electric shock. On the firet two days following adaptation, the animalo were aolgned equaliy to rour subgroups and given 10 trials ench day in which they received weak or etrong shock dealgned to induce $\bar{D}$. They could escape the 
shock by negotiatinr the runway and enteriag the goal hox. Two "weak" shock bubgroups and two "ktrong" shock oubgrours performed under an frrelevant hunger need of o nnd 2 ? hrs. On the third test dey, the four subgroufsof the previnus day were further divited into two ara. making a total of elght suherouos. One buhgroup deriting from each of these latter divistona performed uniter o frrelevant hunger need, On this third tost day ahork was given on the flrat trial only; then the animala wemepiven is additional trials without shock. Amsel proposed that the relevant motivation on these trials wankiety, an emotionaly derlued need, condjtioned hy the previous shork experierce. An analysis of arores for the first two test days showed that running time was not influenced by $\dot{n}$. Shock level was a significant source of varianco. Conversely, the resilts of the third day yileided a signifleant relationship betwen $\dot{D}$ and runnting time. Indeed. the data of 11 four subgroupe are clearly in accord with Huli's theory. In aummary, the ddition of a pimary need ton relevant pribary need failod to increabe D a Inferred from maze performance. On the other hand, the addition of an irrelevant primary need to an enntionaily derived relerant need did increase D. On the hanio of theredata. Amsel concludes that more research must precede 


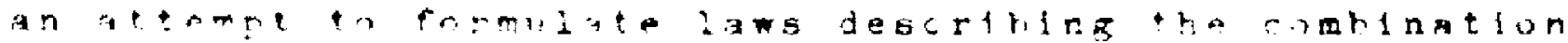
$o f n+t) s t a t a n$

\section{Milipr (Io) has reported ton gtudiea which sufgest}

that nosde may combine tr affest hehavior. hats tratned to negotiate a maze under 4f hra. water trivation when sa: iated for water and nate bunbiy rart he maze faetarthan fimizariytrained fontarlarimals satiated for hoth water anitosd. In the a ame article Milier otated that rats trainod under hungaria a t-maze contniet to ris and makecorrect tirns whengatioted. Hale

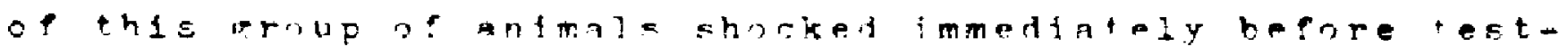

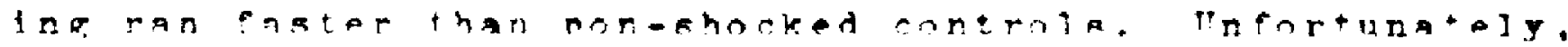
no guantitative data we-p pritished.

Of the studjeg summarfzed dealtho of h consummetory behavior: onIy on (0) has tajled to support the drive summation typothesta. This gtudy when viened along with similar anes suggents that the intenoltvor $\bar{D}$ is critical. The relationshi I hetween D and preparatory hehavior is even more obscure. KendIer's otudy fndicates that the 1 in tenatey of $D$ is central to the problem. Webb repnrta findings which are entirely in agreetent with HuII's iypothesis. though a poselble confounding exista ln his exper1went. The M111er report 10 favorable; homerer, no quantitative data were publiahed. Amael finds positive 


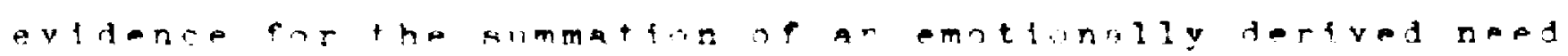
and arimarv need oniv. Tha nead for rumber researeh on this protien is cloarly indirated by the proceding oummary. The present expertment. to reatonod with thif need in view. Ita point of departuap la the Amsel and the

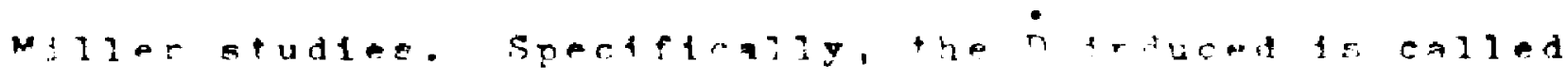
emotionaltiy, viewar as a paraeverativa reaponae followtng pas and noaseasing notivational neopertieg. generated hy fod fripation. The rriterton hehavinge-

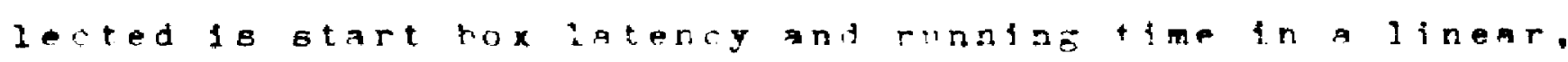
al ley mze. Each drive condition has reen tested at zero, weak. and strong levelo ylelding uniguedrive conditions for nine indenendent groupe. The occasion for drive eummetion has heen provided under condftions whion aprear to ronettute a fair test of the hyrothesia. The ronditione have heon outlined hy sterel and Brantloy as follows: "(a) the drfue level is not alradu maxtmal, (h) the ap-

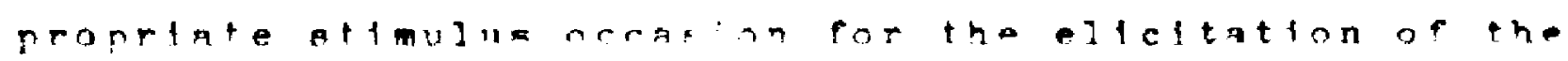
response is presented, and (r) stimuli eltriting competing rosponser are ahsent." ( $24, p .304)$.

Perhapa oymolic statement of Yull's formulation wil further elariev the prefent prohion. The aumation rule, considerably simplifled, 1 s as followa: 


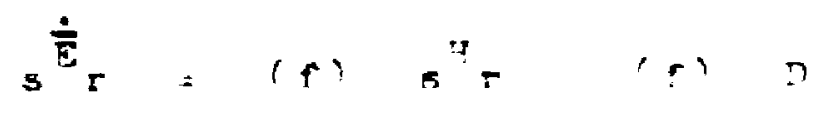

when $D=\frac{\overline{5}}{\dot{0}}+\frac{\dot{5}}{20} \times 1 \%$

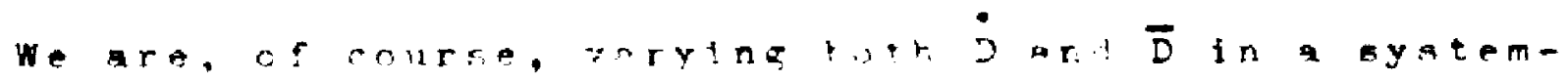

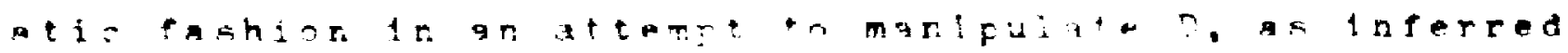
$\operatorname{rrom} \frac{\dot{t}}{\mathrm{E}} \mathbf{r}$. 


\section{MEIHOD}

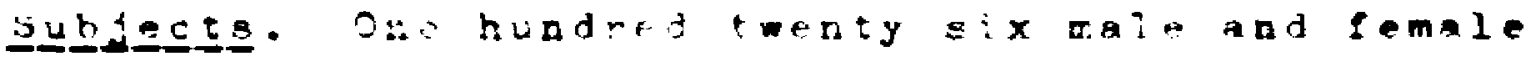
Ibino rats of the Harlan struin werewtilized as So. Their agen ranged from or to 00 tays the the heginning of

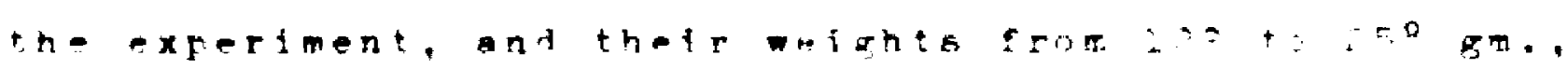

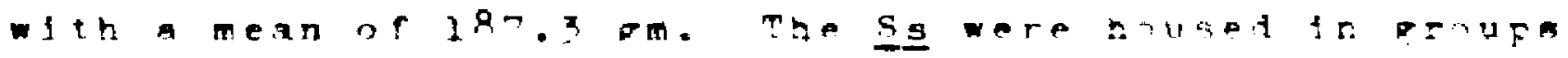

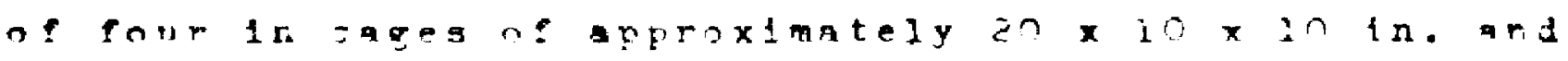
maintained on purina onr chow rberbersand water ad ilh.

AEngratuㅗ. Two linear mazes and ahack on conetteuted the apparatua, The maze wijized for pretratn-

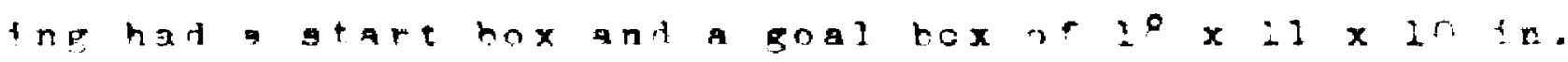

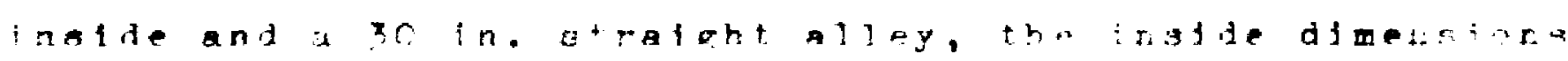

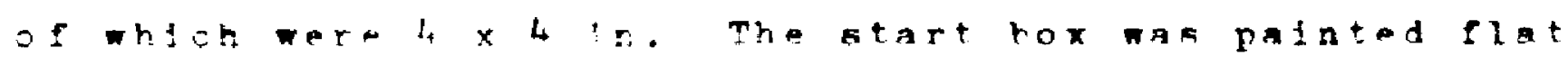
white; the alley ant the goal box, fiat black. Both the gtarthox and the goal box had gulliotine typedoors which when ofened artivated microswlehes controlilne two loctric clocks. These clocks measured atart hox iatensy and running time to the neareat. Oci bec. The trainingteat maze was identieal to tho protraining waze except that the al $1+y$ wan 17 t. 6 in.

The shock apparatus conetsted of a $20 \times 15 \times 14$ in. compartment, the walis of which were palnted with black 
ant wite diggonal stripea. Tho tor was plate glase.

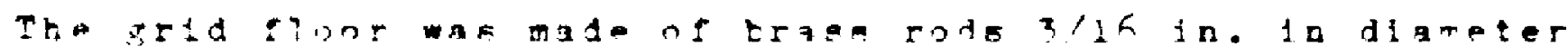
nnt spaced appraximatejy 1,2 in, apart. A shork current wa provided by a constant D.C. source with a rated output of gC5 v. A one meg. resistor was placed in series in the

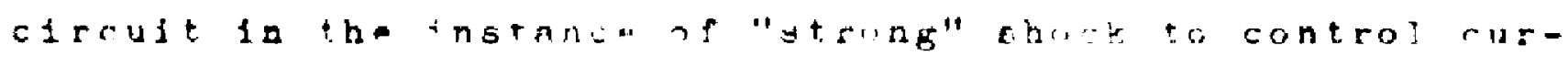

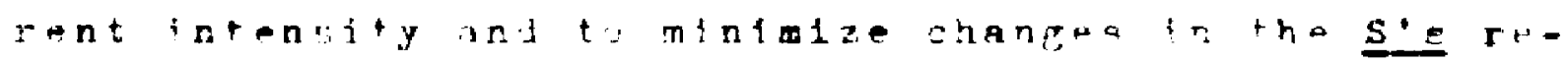
getance. Forthe "wek" ehock a two meg. reststor was

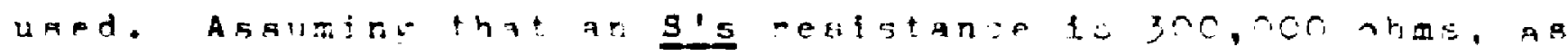

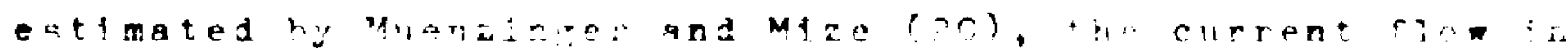

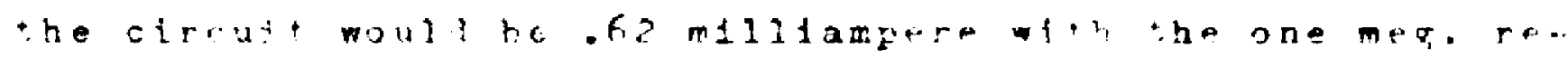

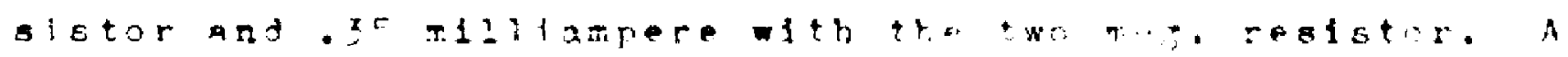

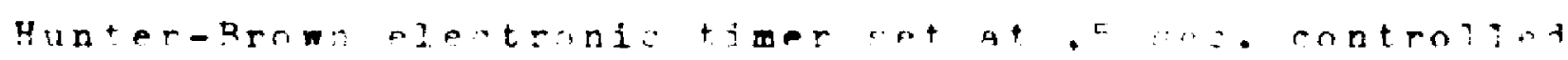
the shork it:rition.

Procedure. The oxperiment was conducted in two aessions, eqch lagting 44 days and consisting of pretrating, trainine. and a teat. The pretraining regimen was deBigned to establish spectelc eating habtts, adngt sa to handilng. and familiarize them with the mage environment. For the first $1^{4}$ days the se were fed wet Purina mash and handled for 1 hr. oth day. Water was aliahle on the handifip table a well a la the home cage. Fellowing this phase of pretraining, they were given onetrial daily for 


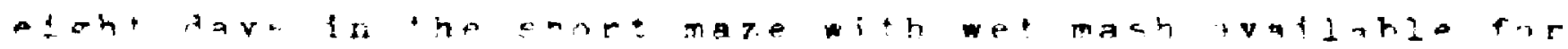

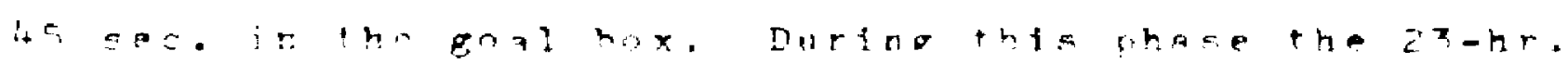

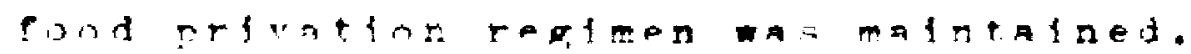

At the termination of thle ?a-tav rerind the tratnIna froper wa heoun. Tratntno wa thential to the

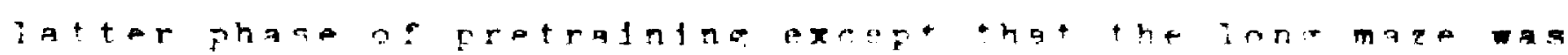

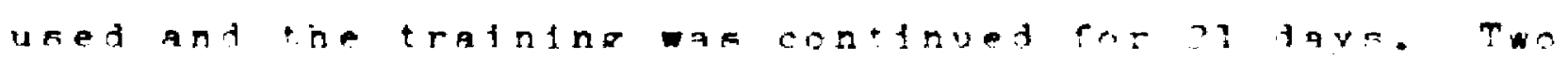

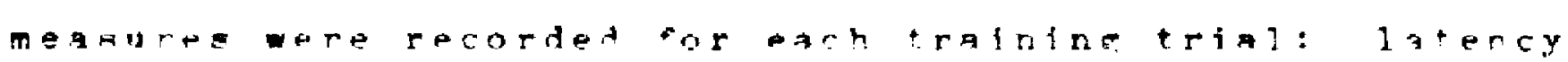
and rinning time. Lateney was ieftred a thatime intert

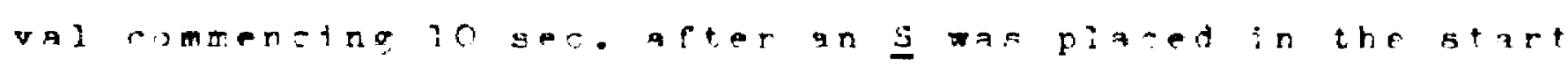
hox and ending when the start hox cloced, $1 .$. wheathe antmal was is the iliey and juat cimb of ine door. Tho Antag: wape placed in the otarthoy farlng opposte the door. Runtng the wa doflaed as tho lnterval between the rlostas of the start box doof int the closing or the goal hox door after the antmal had entered.

The criterion test wa conducted on the lay inmedigtely following tha last tratnlng tag. At this timn the 126 animala were equaliy and randomiy asataned to the nine relis o: a $3 \times 3$ factortal dealgn. No bex bian resulted from this procedure. One dimenaton of this desion consisted of 0 , l? And 23 hrs. food privation, $\bar{D}$. The other repreatented zero. weak, and otrong ghock, $\dot{D}$. Thue the nine groups -111 henceforth be deeignated o-n (non), 


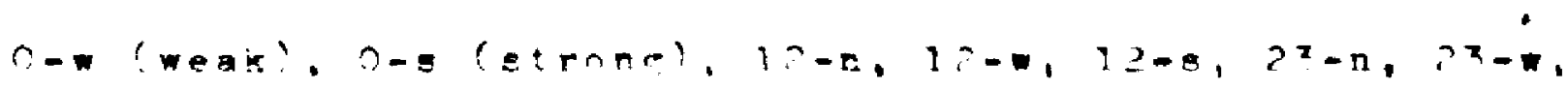
and $2 x-3$ where the numerals rofor th the Antenstiy of and the lettara to $\dot{D}$.

Grnups $23-n, 23-\omega$, and $23-0$ mere tooted under the huger need that prevailed during training. oroupe $2-n$, 12-- and 12-owere allowed to eat forthr.exnctiy 12 hro. Prior to tefting. An fntensive effort was ade to insure that groups $n-n, 0-0$, and $0-5$ werp atiated at the time of topting. This entalled alinwigg the andmale accose to wet mash for 2y hrs. or until they had otopped eating enr rin., whithever tixe was longer, immedintely before teating. Qualitatively, all animalo in these groups anneared lathargic and pariy quitecent.

The tragtments deatgned to frduce emotionality ware intermittent faradis etimulation delivered immediately prior to tha criterion maze run. Trouptrecalvine no shock were elmply exposed to the ohock box for 20 soc. Those recefrigg weak shock ware giren lo oholks of. 35

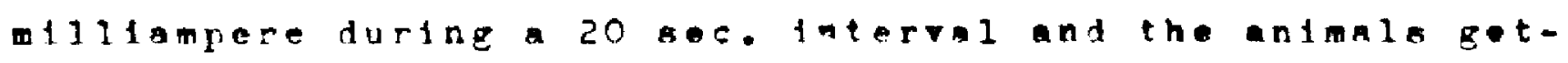
ting strong shrck, 10 shocke t. 67 militeperedurtag the 20 oce. In preitinary otudy some oridence for asuming that the stronger shock producea "aore" emotionality was obtained. Thirty animals had been asolgned equaliy and wthout bias to then, w, and s shock conditions (1dentical to those emplojed in the main oxpergment). Immediately after the trontmento were administered, the animaln 


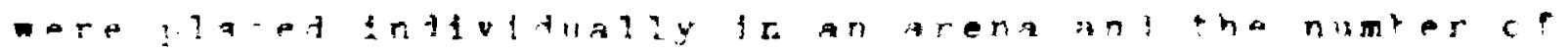

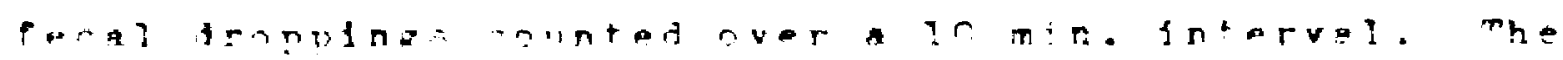

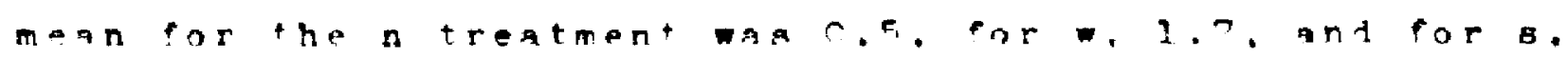

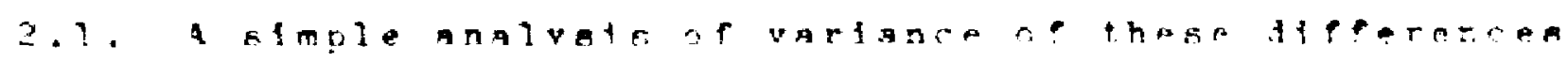

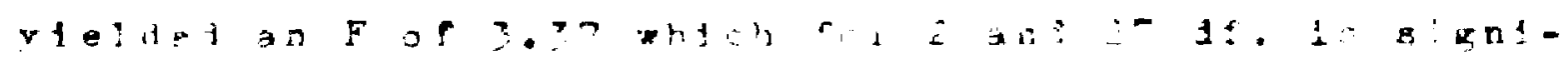

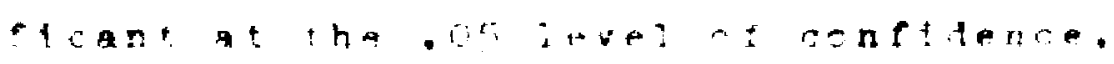
Several precautions wera taket to prevent gerpral-

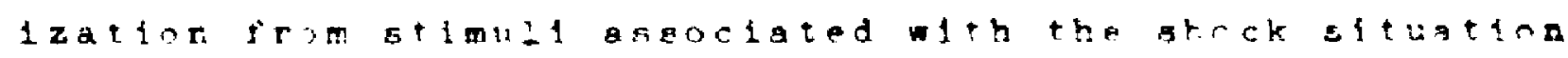
to (a) the shate groupdure was adrtied out by an E who had

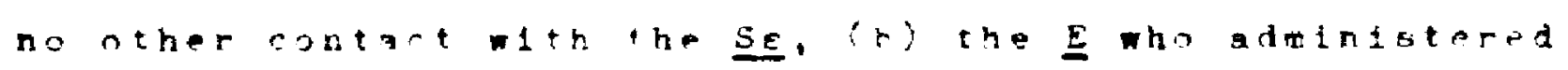

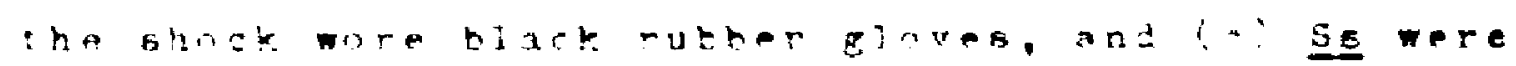

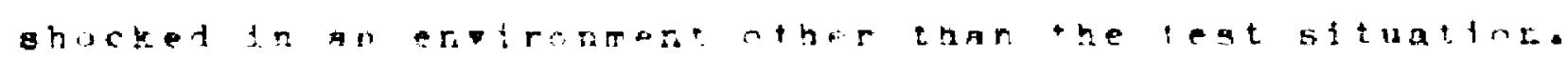
The exace procature groflated of the shock-E taklngthe animat from his eage ant jianingti in the shock box.

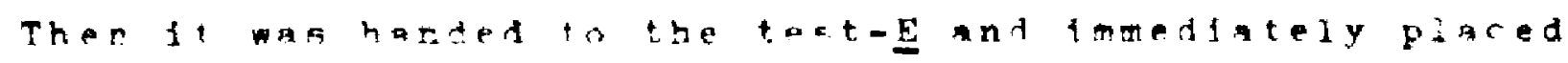
in the ctarthox. Approximateiy f sec. elapoed between the end of thy iagt ehrok ixpule and the placing of the antmat in the stmethox. The petimate of ezrortor this interval is 2 aec. 


\section{จ.5*ITS}

Figure: derictg medtan laterisy a y rigction of tralning days and tratmonts, Parle Tresents median

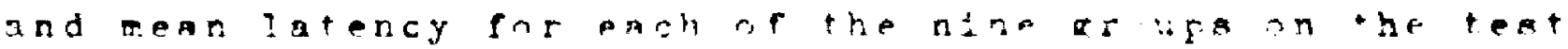

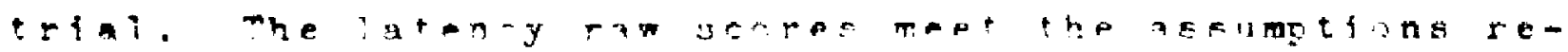

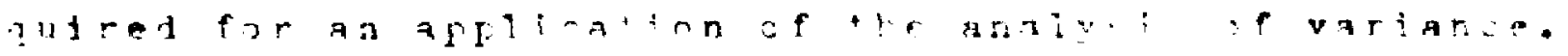

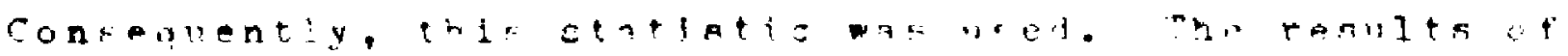

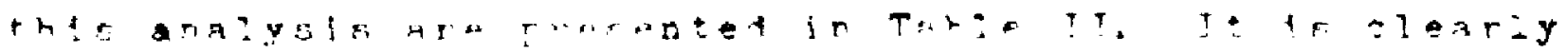
aparent thet the thtonatty or hunior isidimetiv reiated

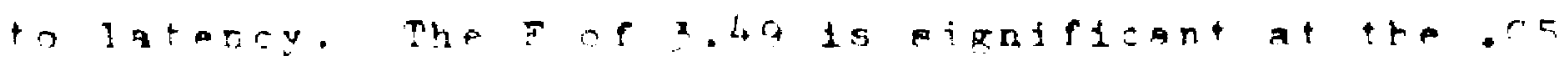
lovel of conftience. Emationality fatiod to infupence

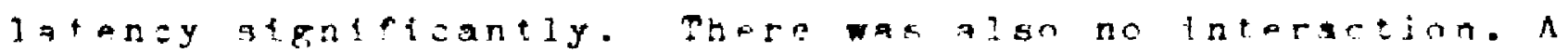
furthwrtact of the effects of emationaity, which la ferhans evon moze orittonj, compared the tect performance or the $-3-n, 23-w$, and $23-5$ grupa with thetr porformance on the last trainirg day. Srouge ? increases in latencyon the teat day of.68 aec. ant.40 sec. Febpectively, whereas group $23-8$ showed a mean decrease of 1.05 Bec., but t-testa indicated that these differences could he atributed to chance. A atatigtical comparison of the tekt scores of groups $23-n, 23-\pi$, and 23-s apert from the other groups is logicaliy contra1.ndicated by the results of the previous analyato of 


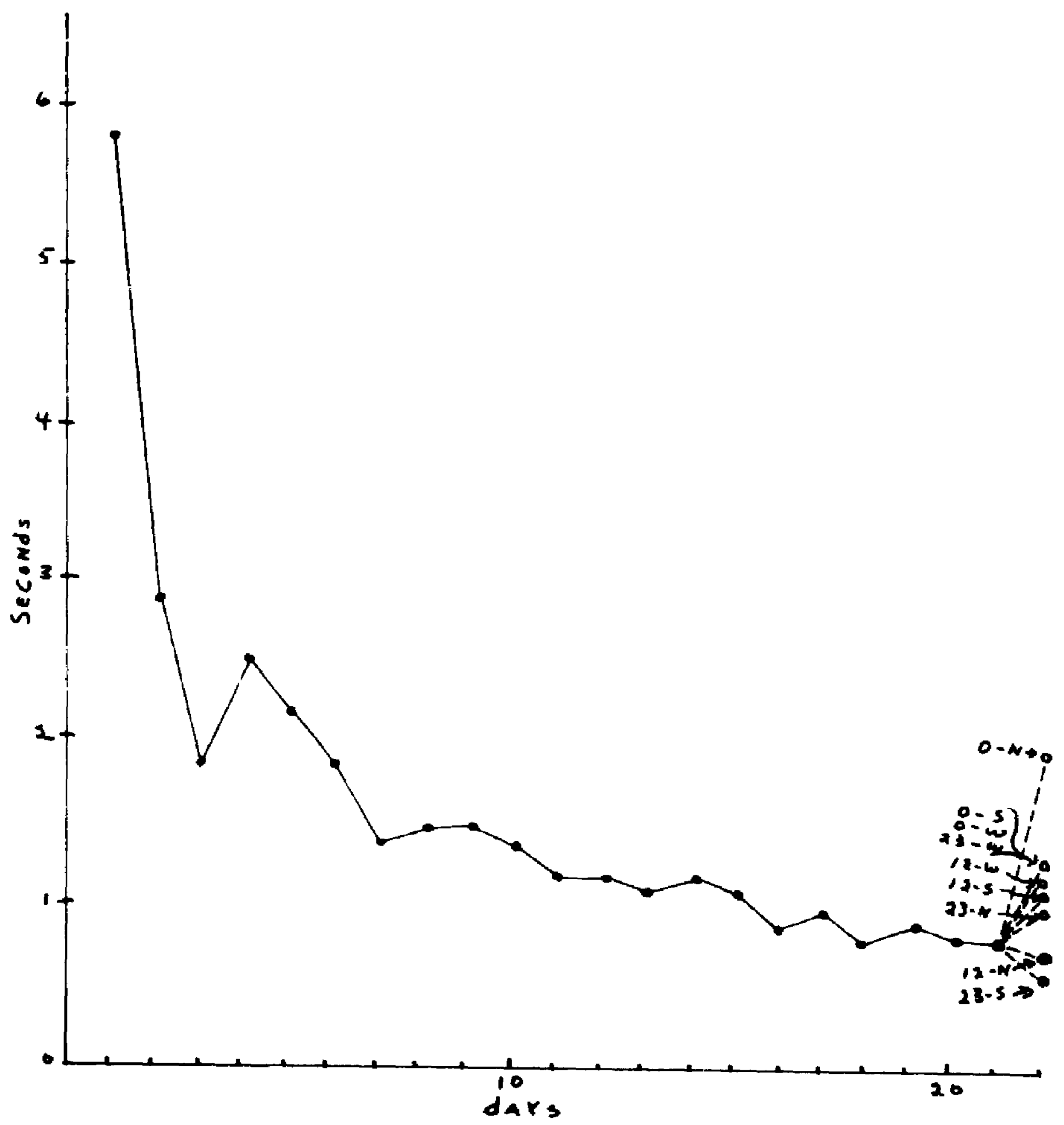


TABLE I

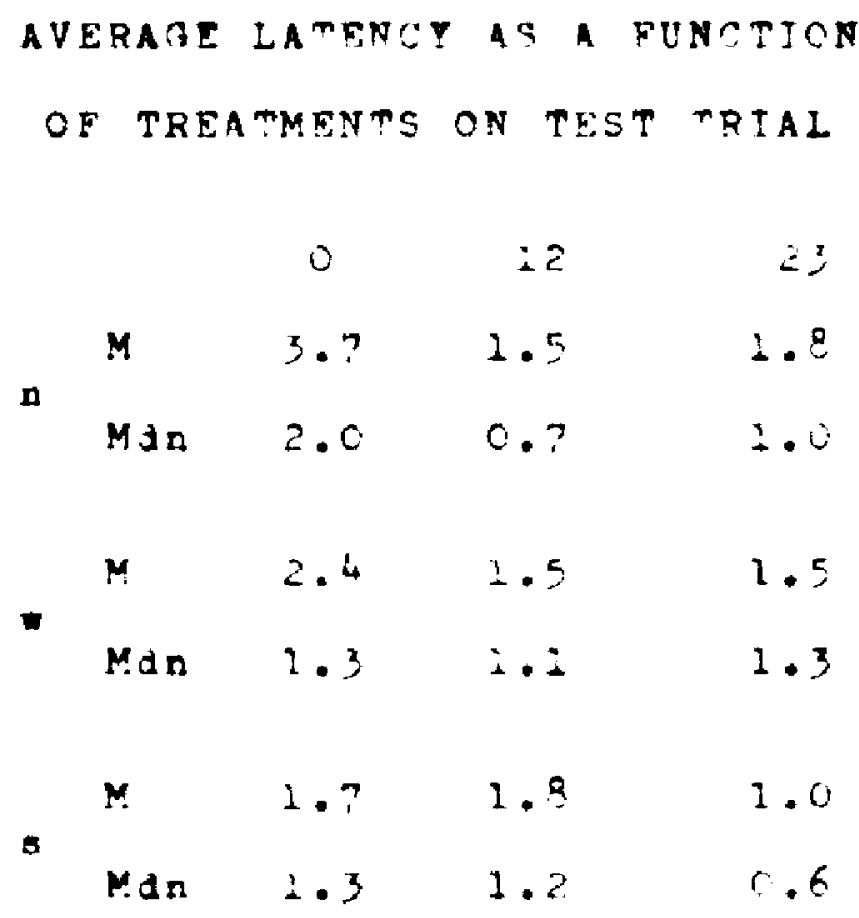


TARE II

\section{STMMARY ANAIYSTS OF VARIANCE \\ OF IATHECY SCORES}

\begin{tabular}{|c|c|c|c|c|c|}
\hline Sourse & & $d e$ & S S & MS & $F$ \\
\hline $\bar{D}$ & & 2 & 35.5 & $=7.75$ & $=40^{\circ}$ \\
\hline 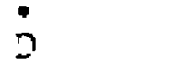 & & 2 & 25.0 & 7.50 & $1.4 ?$ \\
\hline $\bar{D} \times \dot{D}$ & & 4 & 20.14 & 5.26 & 1.00 \\
\hline$n 1 t h 1 n$ & p pa. & 112 & 596.1 & 5.09 & \\
\hline Total & & $1 P 5$ & $667 . C$ & & \\
\hline
\end{tabular}


yariande.

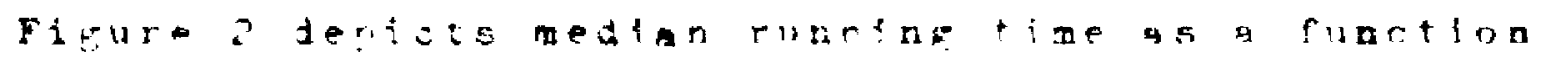
of tratning lojs and trontments. Tat: TII givea tean

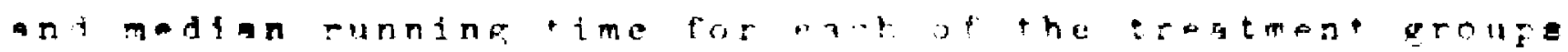

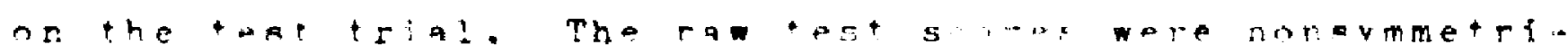

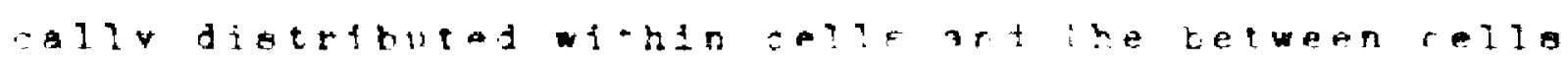

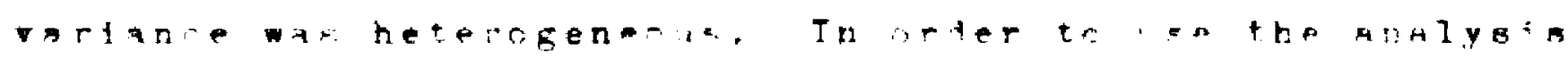

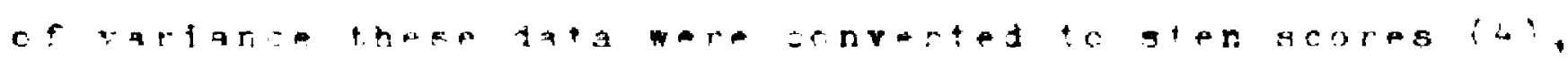

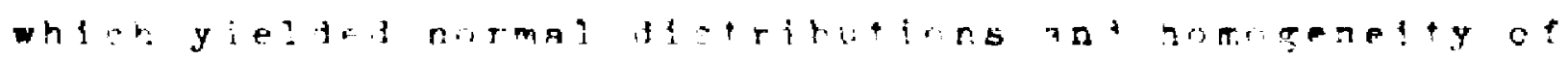
variance betwee relis. Tarie IV summerizes the analyols

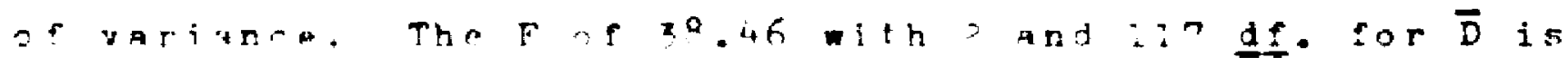
signiflint at heyand the ol lavel of ronflidence. The F

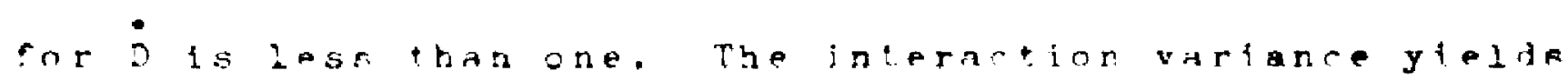

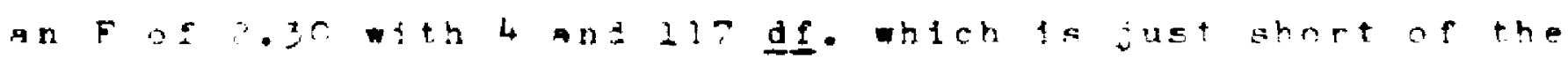
2.45 needed for the of lovel of wofiance. Reference to rable II shows thic toteraction derivas matnly from the differential effocts of emotinnailty uron the pa-hr. groupo when compared to the other grougs. It may he feen that running time is dimectly related to the intenelty of emotionality for the 2z-hr. animals, but tends to he $1 \mathrm{n}-$ versely related for the o-and la-hr. antmals. In this instance, the near atentelcant interaction variance offere some iustiftcation for an indenendent anmlys of the differences between the 23-hr. antralm nlone. Such an 


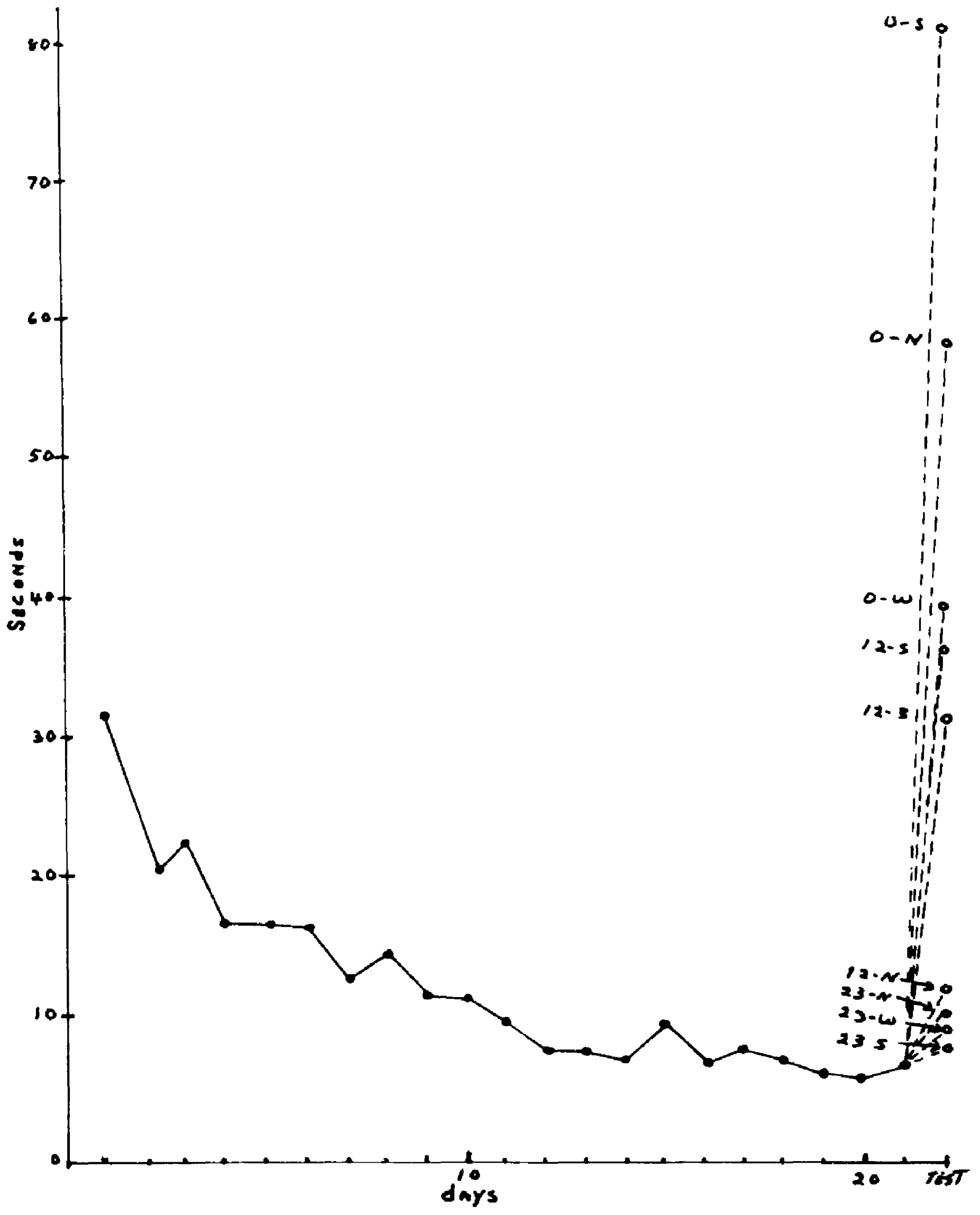




$$
\text { TARE TTT }
$$

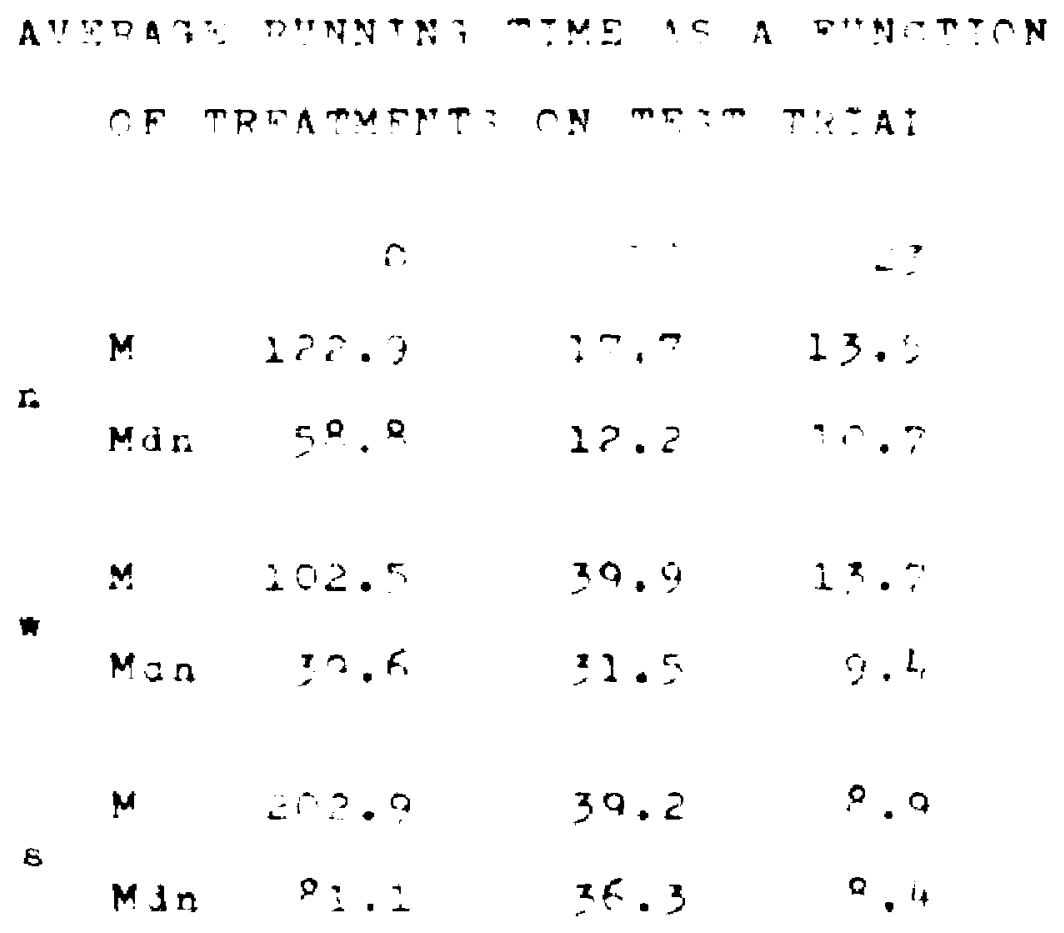


OADLF IV

STMMARY ANALYSIS OF UARIANCE

OF RTNRTMT TIME SCRREJ

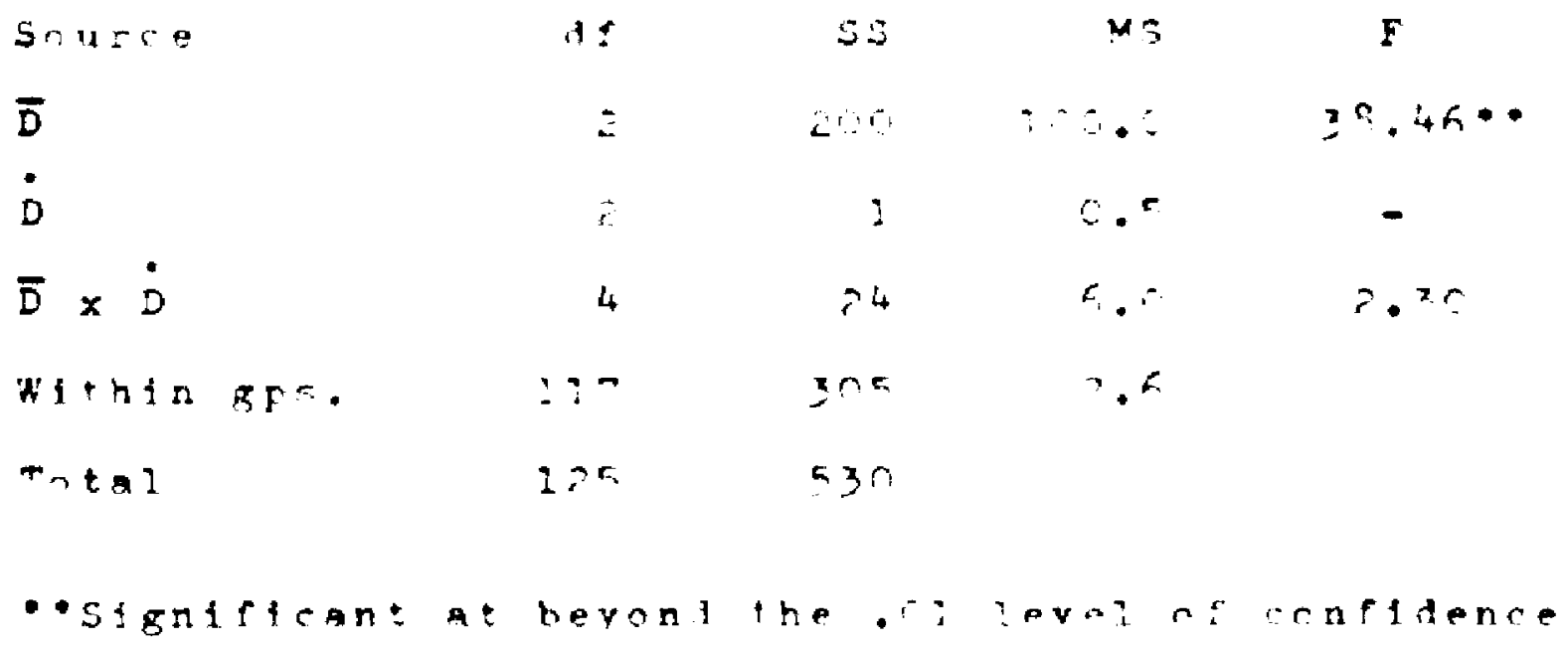




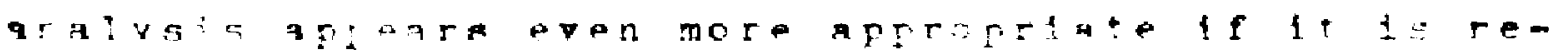
memtared that that antmais mare tceted under rontitions

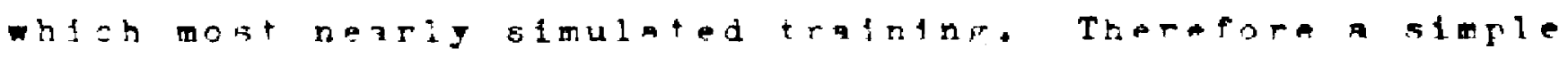
analysta of variance was performed on the transformed

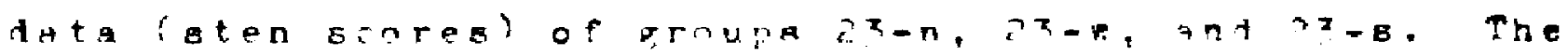
For 2.34 with 2 and 39 tif. for botwong groupe fallo iar shortof glgnifjanoe. Figune 2 shows that the teet performance of these grourg ts alightly poorer than that on the lact trainirg day. The median (raw score) incregsed from 6.4 to G.P gec. A smple otgntest jndicatol this differenie as statistlealiy significant. 


\section{DISCUSSIOI:}

Perhags our most strikinis result is the effect $\bar{D}$ reduction had upon running time. This effect can be clearly observed in Fig. 2 . The reduction of $\bar{D}$ to zero roughly doubles running time, ard, significantly, four animals in these orsups did not reach the goal box during the allotted six nin. (A score or six min. was assigned to these animals for statistical, urjoses.) The effect produced by the reduction of $\bar{D}$ to 12 nrs. is less:ronounced. However, the mean runnin; time for these groups combined is approximately equal to tat at the beginnins of trainin i. Though there is a sionificant increase for the 23-hr, animals, this change is lot appreciable in view of day to day variability. Whether the large decrement for the o- and l2-hr. groujs i.i ue to a loss of the cue function or the energy function ol $\bar{D}$ cannot be determined at this time. The best suess is that it i due to both factors.

To anticipate an argument which may be advanced, the change in procedure on the test day could have had a goneral discuptive effect uon performance. Such a general hypothesis could account for the overall decrement in both running time and latency. Nevertheless, it would 


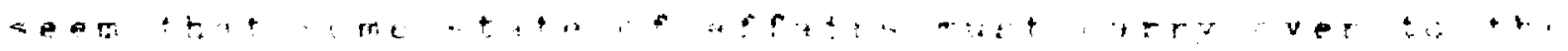

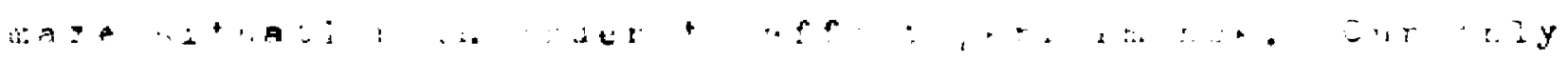
gasmet

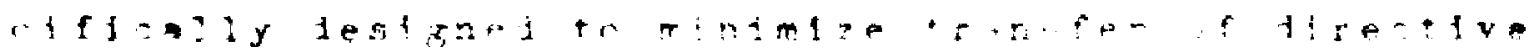

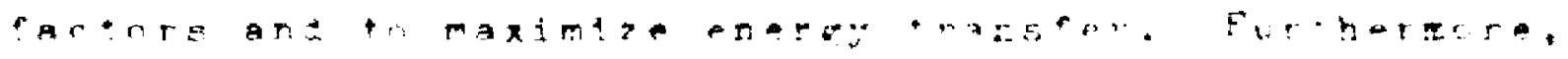

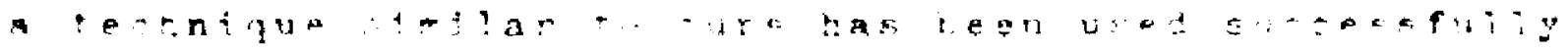

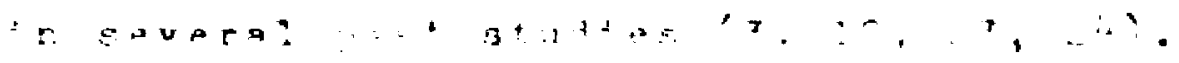

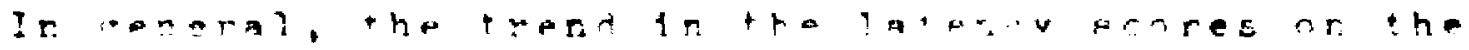

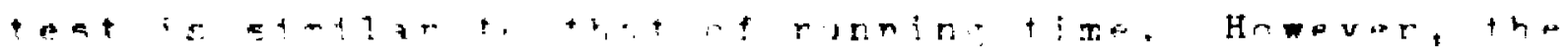

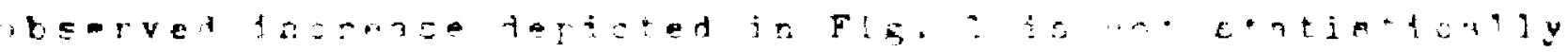

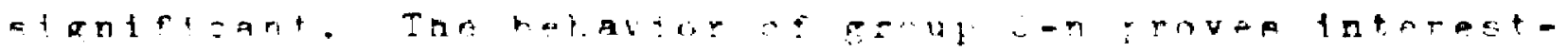

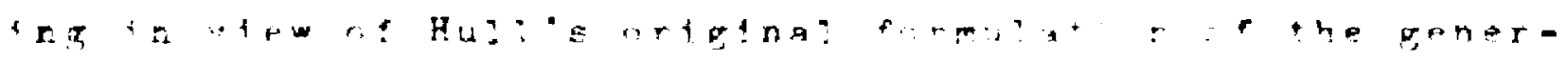

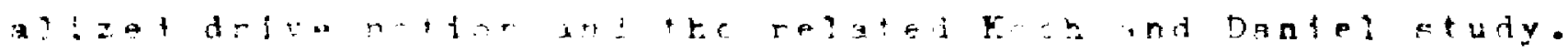

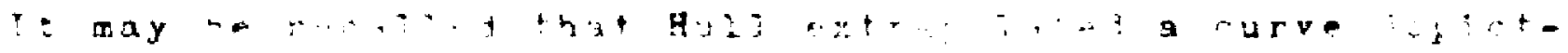

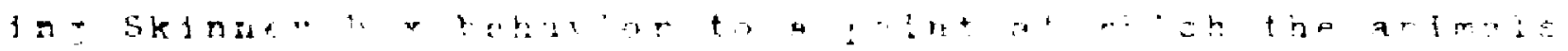

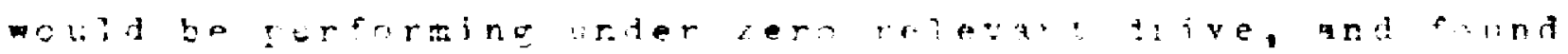

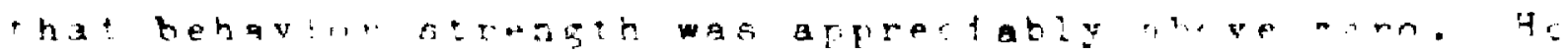

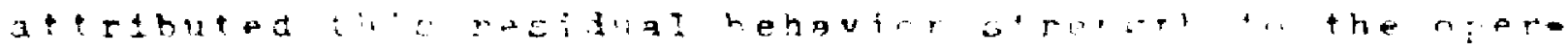

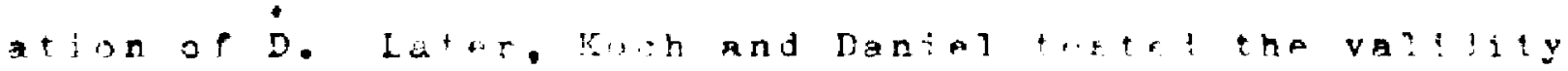

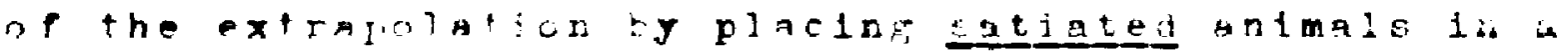

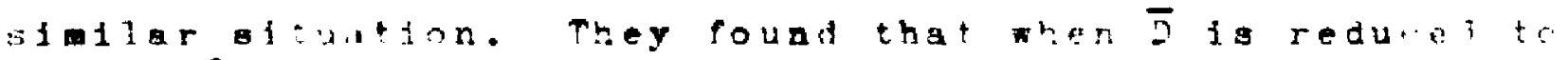

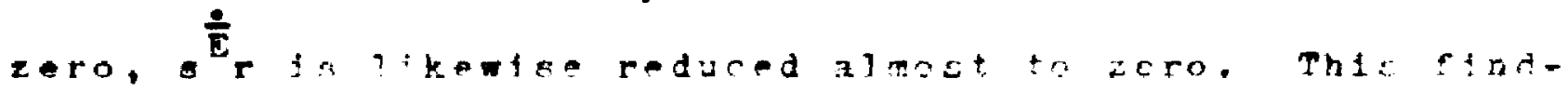

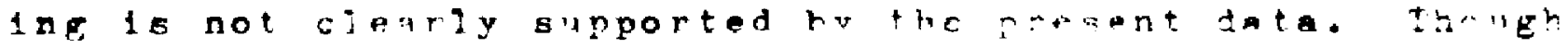
our O-n antmat warevery slow, 1s nit of the 14 in this 
group reached the goal hox within 6 min. Five of these animals were observed to nibble food. Qualitatively. however, the typical behavior of an animal in the maze following exposure to the shock apparatus did not appear to he goal directed. Specificaliy, they had a mincing gait in the alley, were inclined to urinate, and appeared acutely disturbed. For these reasons we tend to believe simple exposure to the shock apparatus induced midemotionality, which, accorifng to the drive aummation hypothesis, should have energized coal directed behavior in this situation. It 1 s felt that this particular result offers no clear evidence for or against the hypothesio.

Our data, viewed in their entirety, cannot be offered in support of Hull's qeneralized drive hypothesis. In those Instances where $\bar{D}$ is 10 w. D should facilitate behavior more than when $\overline{\mathrm{D}}$ ia high. The near signtficant interaction obtained from the analysio of the running tiae data suggests a converse effect. It may be noted, by referring to Table I, that aedian running time for the 23-hr. animalo is directly related to the intensity of whereas the relationship for the o- and $12-h r$ animals tonds to je inveree. No appreciable tateraction is ovident In the latency data. Soveral ad hoc explanations 
can he offered for our negative findings. The tenability of some of these will now be considered.

Perhaps the utilization of emotionality will bear careful scrutiny in view of the fact that many theoristo have considered it a disruptive influence rather than a motivationai state. The best support for using it in the present context is offered by previous experiments in which it has been shown to energize habits set up on the basis of other drives. Stgniflcantly, the operatinns of inducing emotionality in those studies were similar to ours. Farber (9), In a discussion of the relations between motivation and verbal learing, cites several experiments which demonstrate the motivational characteristics of lectric shock, though he does not employ the concept of emotionality. Therefore, alnce the generalized drive hypothesis gains oubstantial support from experiments which used this as a need state, 1 t hardig seems reasonable to discount ita motivational properties in order to rationalize our negative results. A oecond ad hoc explanation for our negative tindings appears wore tenable, and, if valid, requires no modification of the generalized drive hypothesis in 1 to present form. For drire summation to occur, $\dot{D}$ wut not provide cues which elicit competing responses. The habit 
structure underlying the response and associated with the cue accompanying; $\dot{D}$ could be innately determined or conditioned. Amsel (2) and Ambel and Cole (4) have clearIy ahown that, if competing responses are conditioned to cuec associated with $\dot{\mathrm{D}}$, the criterion behavior will undergo a decrement. Farber has catd. "Even in those instances in wich shock is noninformative. i... not related in any systematic way to correct or incorrect response, it is necessary to consider 1 ts response-producing properties. The fact that ohock tends to elicit withdrawal or vocalization, or muscular contraction in rats or human beings, may he a consequence. not of ita drive characteristica. but rather, of its association with either learned or Innate reanonse tendencies. Since shock 1 s an intense stimulus, capable of eliciting a variety of reaponses, 1 t Is not surprising that in certain oituations it mag elicit responseo that are incompatible with those elicited by other otimulus components of the situation" (9, p. 313 ). Though this theorizing provides "way out," it questions the teatability of Hull's hypothesia asoriginalig formu1ated. It might be Inferred from Farber's discusion that an intense state of affairs, such,selectric shock, way Invartably be accompanied by cues which areassociated - Ith habit otructures. If this is the case. and it seems 
highly probable to this writer, then some qualifyling conditions must be introduced which would allow drive sumation, and consequently, the factiltation of behavior to occur. One such condition coult be the intensity of $\dot{D}$. Perhaps mild $\dot{D}$ is accompanied hy cues which are too weak to elicit associated habits, yet which have onergizing effects wen added to a motivational state. This possibility lo sugpested by a previoubstudy (8). Another study (15) offers a converse ougsebiton. however. A second possibility is that the energy contribution of an introduced $\dot{D}$ is relatively greater than the decremental effect of its directive tendencies. This could or could not depend on the drive intensity. Of course, there are possibly other equally likely qualifications hich could be introduced. At our present stage of knowledge, however, there is scant experimental evidence to support these opeculations. Certainly our present data are not augpestive. If one's theoretical Inclinations lead to some alternatfve other than an essential modification of the hypothesis, then the generality of the hypothesis may be curtalled by lititing the types of motivational otates to which it is applied. Hu11, In a later paper, has adopted this position. He sald, "At least some drive conditions tend partialiy to 
motivate into action habits set up on the basis of different drive conditions" (1?, p. ?).

Brown. Meryman, and Marzocco, in a paper which appeared after this experiment was completed, reported findings which do suggest a modification of the general1zed drive concept. These investifatora deviaed two experimenta to test the perouerative effects of electris shock upon the otartie response to an auditory stimulus. In conclusion they stated, "The reaulta of both exneriments aree in indicatina that immedintely after the cessation of shock, atartle-reaponse amplitude 1 s depreseed, not enhanced. With further passage of time, the reaction shows a smooth, negatively accelerated recovery curve. In hoth expertuents, the reaction seems to pass over into a supernormal phase after ahout 5 sec.. but the effect is not significant by usual statistical criteria" (6, pp. 193-194).

These resulta provide a possible explanation of our finding. It may be recalled that our animalo weretraumatized and immediately placed in the maze start box. We have estimated the time elapoing between the final ghock impulae and/or box exposure and the placing of the animal in the start box to he 6 sec. \pm 2 aec. Reference to the "recovery" curves published by Brown et al indicates that 
behavior should at this time be near the level they observed in their nonshocked animals. The net result would be no effect. For our 23-hr. animals, the effects of traumatization are, Indeed, negligible.

Fingliy, the criterion behavior may prove central to the protiem. Those studies concerned with consummatory behavior have generally reported nositive findinga. on the other hand, positive evidencefor, racilitative effect of $\dot{D}$ uron preparatory behavior is rare. Kendler lone found positive evidence for drive oumation in a skinner box situation, and this finding was contingent upon the intensity of $\dot{D}$. Webb reported positive results wen the criterion hehavior is door-opening behavior. though he used two need states which may be physiologically confounded. Amoel falled to observe an increase in maze performance when a hunger need was added to a motivational complex in which the need state was emotionality. pehavior was factijtated when the dominant need otate was changed to anxiety. Only Milier reported positive resulta from a test which resembles the present one.

In conclusion, our data canot he offered in supoot of Huli's concept of drive sumation. On the other hand. to propose that they constitute evidence against the hypothosis implies confidence in the fairness of our teat 
which we do not feel is entirely justified. At best, we can only offer these empirical data as evidence upon which to base theorizing at some later time, after more facto have been established. 


\section{SUMMARY}

In order to test Huli's drive sumation hypothesis, 126 ratg were trained to run a linear, alley maze whilo under 23-hr. hunger need. Following 21 datiy tratning trials the antmals were assigned to nine treatment groups consigting of the possible comblnations of 0,12 . and 23 hrs. food privation, as a relevant need, with zero, weak and otrong faradic stimulation ag an irrelevant need. The "test" consisted of t trial similar to a training trial. The otate induced by the faradic stimulation was called emotionality and viewed as possesing motivational properties. Both start box latency and maze running time were utilized as criterion behavioro. The findings were mainly negative. The criterion behavior was not significantly influenced by the introduction of an frrelevant need into the motivational conplex. As expected, changes in the relevant need otate did significantly affect latency and running time. A near olgnificant relevant need times irrelevant need interaction was observed. Several posalble ways of modifying the theory to account for more of the present experimental data were discusoed. It was concluded that the present data provided no definitive evidence either for or againet the theory. 
RI RIIOAPAPFT

1. Amsel. A. The combination of a primary apetitional need with primary and secondary emotionalig-derived needs. I. exp. Psychol.. $1050,40,1-14$

2. Amse1. A. The effect upon level of consummatory response of the addition of anxiety to a motivation complex. I. exp. Psychol.. 1950. 40, $709-715$.

3. AmseI, A. \& Maltzman, I. The effect upon generalized drive strength of emotionality as inferred from the level of consumatory response. $J$. exx. PEychol. 1950, 40, 563-569.

4. Amsel, A. \& Cole, K. F. Generalization of fenrmotivated interference -1th water intake. I. exp. Psychol., 1953, 46, 247.-247.

5. Brandauer, C. M. A confirmation of Webb'a data concerning the action of irrelovant drives. J. exp. Psychol.. 1953, 45, 150-152.

6. Brown, J.S., Mergman, J.H., Marzocoo, F. N. Sound-induced startie as a function of time s Ince shock. J. comp. phyeiol. Psychol.. I956, 49. $190-194$ 
7. Canfield, A. A. Sten scale. Educ. Dsychol. Messmt., 1751, 11, 295-247.

8. Ell1s, N. R., Slegel, P. S., Bohl, S. A. The effect of emotionality upon the food intake of the rat. Paper read at Southeastern Paychol. Ass'n. Atlanta, May, 1955.

9. Farber, I, E. The role of motivation in verbal learning and performance. Faychol. Buil.. 1955, 2ㄹ. $311-327$.

10. Finch, G. Hunger as determinant of conditional and unconditiongl salivary response ragnitude.

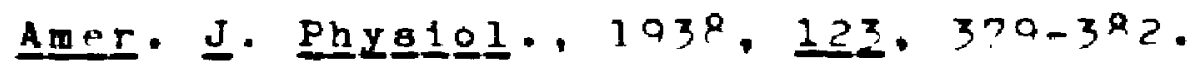

11. Hul1. C. L. Erinciples of hehavior. New Tork: Appleton-Century, 1943 .

12. Hull, C. L. A beharior system. New Haren: Yale Univer. Press, 1952.

13. Jones, M. R. (Ed) Gurrent theory and research in motetvation: 1953. Ifncoln. Nebr.: Nebraska Univer. Press, 1953.

14. Jones, M. R. (Ed) currrent theory and research in motiration: 1954. Lincoln, Nebr.: Nebraska Univer, Press, 1954. 
15. Jones, M. R. (Ed) Current tieory and research 1 In motivation: 1955. Lincoln, Nebr.: Nebraska Univer. Press, 1955.

16. Kendier, H. H. Drive Interactinn: I. Learning as a fuction of the simultaneous presence of the hunger and thirat drives. J. exp. Foychol.. $1954,25,96-109$.

17. Koch, S. \& Dantel. W. J. The effect of satiation on the behavior mediated by a habit of maximum strength. J. exs. Foychol., 1945, 25, 167-187.

18. McClelland, D. C., Atkinson, J.W., Clark, R. A., \& Lowe11, E. L. The achievement motive. New Pork: Appleton-Century-Crofts, 1953.

19. Milier, N. E. Theory and experiment relating paychoanalytic displacement to otimulus response generalization. I. aㅡ으료. 으모. Psychol.. $1948,43,155-178$

20. Muenzinger, K. F., \& Mze, R. H. The onditivity of the wite rat to electric shock: Threshold and skin resistance. J. comp. Parchol., 1933. 15. $139-148$.

21. Perin, C. T. Behavior potentiality a a joint function of the aunt of training and degree of hunger at the time of extinction. J. exp. Parcho1.. 1942, 30,93-113. 
22. Siegel, P. S. Alien drive, habit otrength, and resistance to extinction. I. 도모. Pgychol. $1945,39.307-317$

23. Stegel, P. S. \& siegel, H. S. The effect of emotionality on the water intake of the rat. I. comp. physiol. Psychol. 1945, 42, 12-16. 24. Siegel, P. S. \& Brantley, J.J. The relationship of emotionality to the consumatory response of eating. I. exp. Psychol..1951, 42. $304-306$.

25. Skinner, F. F. The behavior of organisma. New York: D. Appleton-Century Co.. Inc.. 1939. 26. Strange, J.R. The effect of an irrelevant drive on the raction tendency specific to another drive. I. gen. Pgychol., 1954, 2I, 31-40.

27. Webh. H. B. The motivational aspect or an 1rrelevant drive in the behavior of the white rat. J. exp. Psychol. 1949, 29, 1-14.

28. W1111ams, S. B. Resistance to extinction as a function of the number of reinforcements. J. exp. Psycto1. 1938, 23, 506-522.

29. Wohl, S.A. Tho effect of emotionality upon the food intake of the rat. Unpublished waster's thesis. Untrer. of Alabawa, 1955. 
30. Zener, K. E. \& McCurdy, प. 3. Analyats of motivational factora in conditioned behavior: I. The different effect of changes in hunger upon conditioned, unconditioned, and spontaneous ealivary oecretion. J. Peychol., 1939, 8, $321-350$ 


\section{VITA}

Norman R. Ellis was born September 24, 1924 . In Springrilie, Alabama. He attended Ragland Elementary School, Ragland, Alabama, from 1930 to 1936 , graduatigg wth a diploma. He attended Douglas High School. Douglas, Alabama, from 1936 to 1942 , graduating witha diploma. In 1948 he entered Howard College, Birmingham, Alabama, and in 1951 graduated with an A. B. degree. At Howard College he majored in Poychology and ainored in English. In June, 1951, he entered Oraduate school at the University of Alabama, and in 1953 received an M.A. degree with a major in general experimental poycholog. In September 1952, he entered Loulaiga state Univeraity to puraue work leading to the Ph.D. degree in general experimental Paycholofy. For the first fow monthoupon entering L.S.U. he helda research assistantohip in the Department of Psychology. Subsequentiy, he was promoted to the position of research asooctate and held this position unt11 August. 1954. These two positions were related to research for the O.s. Air Force contracted by the Department of Poychology. In september, 1954, he returned to the University of Alabama and held the position of Acting Aselotant Profeesor of Paychology for the academic Jear 1954-55. He returned to L.S.0. In June, 1955. 
42

and held an Instructorship in the Department of paychology during the summer session 1955. During the academic year 1955-56. he held a southern Fellowship which permitted him to complete requirements for the PhD. dore. Since June, 1956, he has held the postation of Clinical Paychologiot te the state colony and training school, Pinevilie, Louis tana. 
EXAMINATION AND THESIS REPORT

Candidate: Norman R. Ellis

Major Field: Psychology

Title of Thesis: "The Immediate Effects of Emotionality Upon Behavior Strength"

Approved:

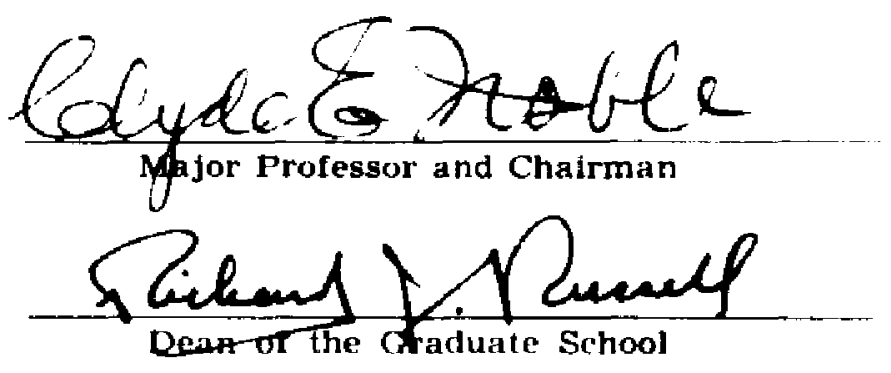

EXAMINING COMMITTEE:
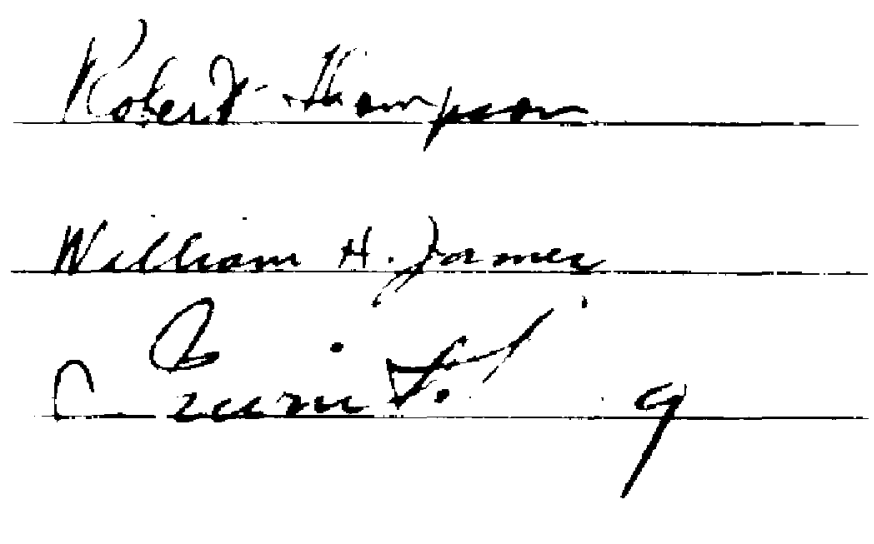

Date of Examination: 21 September 1956

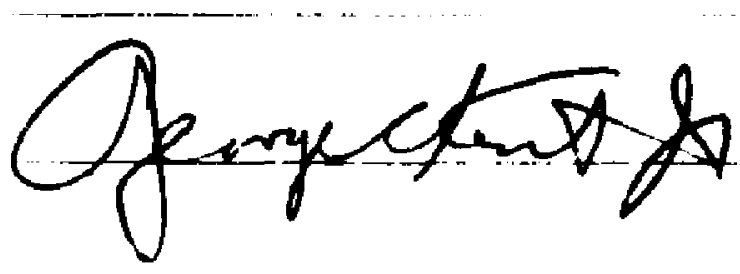

